\title{
Education During the American Occupation of Haiti, 1915-1934
}

\author{
A. J. Angulo, Ed.D. \\ Winthrop University
}

\section{ABSTRACT}

This paper seeks to contribute to this line of research by examining America's first occupation of Haiti from 1915-1934. As with the occupations of Cuba, the Philippines, Puerto Rico, and the Dominican Republic, the U.S. installed a military government in Haiti. American military officials had virtually complete control over the operations of a parallel, client Haitian government. Unlike other occupations, however, this story begins, ends, and is shot-through with educational concerns. It begins with lessons about Haiti taken by the Woodrow Wilson administration shortly before the U.S. invasion in 1915. The consultants they turned to for advice - particularly captains of the American financial industry with large investments in Haiti - significantly coloured the way they approached the country's problems and potential. The story ends with Haitian protests over U.S. imposed educational reforms, protests that spread, intensified, and led to the end of the American occupation in $1934 .{ }^{1}$

\section{RESUMÉ}

Cet article s'intéresse à la première occupation d'Haïti par les États-Unis de 1915 à 1934. Comme lors des occupations de Cuba, des Philippines, et de la République Dominicaine, les États-Unis ont installé un gouvernement militaire en Haïti. Des officiels de l'armée américaine contrôlaient, en parallèle, les opérations du gouvernement haïtien. Contrairement à d'autres occupations, du début à la fin, l'éducation a été considérée comme un élément clé. L'histoire commence avec les leçons sur Haïti apprises par l'administration de Woodrow Wilson juste avant l'invasion de 1915. Les experts consultés — en particulier de puissants investisseurs œuvrant en Haïti - ont grandement influencé la manière d'aborder à la fois les problèmes et le potentiel propres à ce pays. L'histoire se termine au son des protestations contre les réformes en éducation imposées par les États-Unis, un phénomène qui se répandit, s'amplifia et mena à la fin de l'occupation américaine en 1934.

Since the events of 2001, historians have paid a great deal of attention to the idea of "American empire." Howe, Ferguson, Maier, Nugent, and others have brought about a renewed interest in the well-worn topic of twentieth century American expansionism. This literature typically focuses on the social, political, economic, and military histories of U.S. interventions abroad and their foreign as well domestic legacies. 
Until recently, far less attention has been given to the education policies implemented by U.S. officials overseeing the military occupations. The work of such scholars as Anne Paulet, Jose-Manuel Navaro, and Judith Raferty have begun the process of unearthing these episodes in American educational history. ${ }^{2}$

Between the beginning and the end of this occupation, U.S. military officials decreed how Haitian taxes would be spent on education, decided which programs best-suited Haiti's children, and determined that some teachers merited preferential treatment. Throughout this period, Haitians didn't take these decisions lightly. Mass demonstrations erupted and ultimately turned into a revolt over the influence of American capital in Haiti. The cause of education represented Haiti's struggle for the right of self-determination. How the two sides approached the struggle sheds light on what the occupation wanted from Haiti and what Haitians wanted for themselves. Their differences over education reveal the great gap between the real and the ideal in U.S. foreign policy toward Haiti from 1915 to $1934 .^{3}$

\section{Consultants}

"Dear me, think of it," said William Jennings Bryan in 1912, "Niggers speaking French!" At the time, Bryan was Woodrow Wilson's Secretary of State, learning about Haiti, and in charge of U.S. foreign policy toward the country and region. ${ }^{4}$

His lessons about Haiti came from the American manager of the country's most important financial institution, Banque Nationale. It is ironic that he turned to bankers for advice. Bryan loathed them, especially those known for loan-sharking and exploitation in Latin America. But he felt he had little choice. The very real possibility of an American invasion of the country increased during the first years of Wilson's term. The banker to whom Bryan turned and who helped him most was Roger L. Farnham.

Farnham knew quite a bit about Haiti, but he was hardly a disinterested player in the events that were to unfold. As Vice-President of the National City Bank of New York and of Banque Nationale in Haiti, as well as President of the National Railway of Haiti, the stakes for Farnham were quite high. An American invasion and occupation of the country would be a significant boon for him and his circle of Wall Street speculators. Putting American combat boots in Port-au-Prince had the potential of turning their risky investments into stable, secure ones almost overnight. This was hardly the kind of justification that Bryan would appreciate, since it would require asking the American taxpayer to subsidize investment risks for the purpose of private profit. But he warmed to these New York financiers who wanted exclusive control of Haiti's debt and, to secure their investment in the country, Haiti's customs house as well. They convinced Secretary Bryan to send marines into Haiti the year before the 1915 invasion. In that mission, troops removed $\$ 500,000$ worth of Haitian government gold from the Banque Nationale, shipped the funds to New York, and deposited them at National City Bank - all without a single shot fired. The idea was to force Haiti's European creditors, who'd made multi-million dollar loans, to negotiate with the U.S. rather than Haiti. At the same time, American military officials began 
preparations for a full-scale invasion and occupation in case "local authorities admit their inability to protect foreign interests." Within the year, the opportunity to use the plans came when an angry Haitian mob turned against Haitian President Vibrun Guillame Sam, whose term was marked by suppression of political dissent. President Sam's overthrow and assassination set the stage for the U.S. invasion. ${ }^{6}$

While Farnham continued to tutor Bryan on American economic interests in Haiti, Wilson's team quickly began assessing the humanitarian crisis enveloping the country. The State Department spoke firmly of the "humane duty" the U.S. had in addressing the political disorder and potential famine. Stability, freedom, and democracy became the administration's refrain. These ideals, however, only reveal part of the picture; they hardly provided the sole or even primary impulses for invading and occupying a sovereign country. On twenty previous occasions since 1857, the U.S. had dispatched warships to visit Haiti's ports to protect American lives and property. What made Bryan's situation different in 1915 was the level of American investment in Haiti, increasing competition from European investors, a perceived threat from German military interests in the Caribbean, and Haiti's political and economic instability. At bottom, U.S. economic and military interests commanded great influence over the decision to intervene and the decision to occupy. ${ }^{7}$

To Farnham's circle, the occupation meant greater financial control over Haiti. They assumed managing roles in the country's finances and wielded influence over how Haitian taxes would be spent under U.S. governance. They also received a much sought-after prize for foreign corporate interests when the occupation rewrote the Haitian constitution. The constitution prior to the invasion explicitly made foreign landownership illegal. Haitians held sacred the idea that Haitian land was to be owned by Haitians. But this was an offensive legal obstacle to large-scale American agricultural, timber, and mining interests. In a conspicuous nod to these interests, the occupation government removed the obstacle. Franklin Delano Roosevelt, who was then Assistant Secretary of the Navy, later admitted to personally having rewritten Haiti's constitution, thereby opening the door to U.S. corporate control over Haitian soil. ${ }^{8}$

Presidential candidate Warren Harding expressed disgust about corporate and military meddling in the affairs of other countries during the campaign trail in 1920 . He told the American public that the U.S. shouldn't be in the business of writing a constitution for a sovereign nation, much less trying to "jam it down their throats at the points of bayonets." After campaigning against this "rape of Haiti," little changed once Harding won the election and moved into the White House.

The occupation, beginning with Wilson's invasion in 1915, continued largely unchanged over the course of five U.S. administrations because each delegated much authority to American military commanders. And these commanders held a tight grip over the country. By controlling the government revenues and customs houses - in addition to Haiti's land policy and constitution-American officials had veto power over the provisional, parallel Haitian government. The occupation had the power to withhold the salaries of Haitian politicians and to revoke funds for unauthorized projects. Haitian leaders quickly learned it was futile to resist U.S. decision- 
making when the power of the purse wasn't theirs. The one area of Haitian life the American military government in Haiti didn't have explicit control over was education. Absent from any of the original post-invasion agreements signed between the U.S. and Haitian governments was mention of schools, colleges, or universities. The agreements, intended to legitimize the authority of the occupation, allowed for an almost complete transfer of control over Haiti, except for education. That oversight left an opening. It gave Haitians a sense of control over the future of their country not found elsewhere. ${ }^{10}$

\section{Control}

When it came to education, occupation officials shared much in common with what Farnham envisioned for Haiti. What the country needed, he believed, was a "good deal of development" through foreign capital and "some time to educate the Haitian to become a good laborer." As he understood it, with the aid of the right institutions, Haitians could be trained to provide the labour force needed to support American banking and commercial interests. ${ }^{11}$

If there was one person who could make Farnham's vision a reality, it was General John H. Russell. He was the most powerful man in Haiti and led the occupation for over a decade. As head of American forces in the country, he had authority over the government's revenue and almost complete influence over the Haitian government. The United States government created the special position of "High Commissioner "of Haiti in recognition of his achievements. With all of this influence came the responsibility of charting a course for developing the nation's institutions and infrastructure. Russell embraced the Farnham view of things when he said that "education and civilization march hand in hand. The introduction of railways and good roads and the opening of certain agricultural sections by foreign capital will, in time, have a civilizing effect on the natives." Russell wanted American capital to pour into Haiti; he wanted businesses, industries, and large-scale agricultural interests to serve as Haiti's most powerful educator. His faith in American capital was highly coloured by his lack of faith in Haitian potential. "The peasants," he said, "who form the mass $(85 \%)$ of the population and who have so long been held by their literate brothers in a backward state, have the mentality of a child of not more than seven years of age reared under advantageous conditions." According to the General, American investment was the solution to the country's problems. ${ }^{12}$

Russell's views on capital and the Haitian "mentality" had immediate consequences for Haitian education. His policies hardly budged the ninety-five percent illiteracy rate the occupation had inherited. School enrollments increased from three percent to twenty-five percent, but this was underwhelming considering the goal of Haitian self-rule and the stagnant literacy rates. Despite unflattering statistics, Russell decreased the total education budget by twenty percent when comparing funding for $1914(\$ 423,000)$, the year before the U.S. invasion of Haiti, with that of 1920 $(\$ 340,000)$, the second year under his command. ${ }^{13}$

Russell had little interest in promoting literacy or traditional schooling, but instead 
favored programs that would benefit the work of foreign capital such as industrial and agricultural education. As head of the American occupation, he speculated about the nature of the mind to support his preference. Mass literacy education, he asserted, "does not teach them to think. When reading the mind is passive. It requires argument to be active; and reading a party paper presenting only one side of the case, they think only one line." He suggested that literacy had little to do with democracy and struck reading instruction from his list of priorities. Far more valuable, Russell claimed, was teaching "each individual a trade, to make each citizen an asset." According to him, only two kinds of schools had any place in Haiti: "The industrial school is necessary for the proper education of the entire mass of the children of the cities of Haiti. In the same manner, the agricultural school is necessary to the entire mass of children in the rural districts." While this hardly tells the whole story of Russell's thinking in terms of American capital, education, and democracy, it clearly offers insight into his policies. It's as close as he ever came to explaining why he made the most significant education-related decision of his career. ${ }^{14}$

In 1922, Russell began one of the largest educational reform efforts in Haitian history. After failing to convince the Haitian government of the need to create a national network of industrial and agricultural schools, Russell decided to take matters into his own hands. He radically increased funding for the Department of Agriculture with the intent of starting an entirely new system of education, one that would compete with the traditional, classical schooling offered by the National Schools under Haiti's Ministry of Education. With these new funds, he established the "Bureau of Technical Service of Agriculture and Vocational Education" as a division within the Agriculture Department. The division was to supervise the development of new institutions for technical education. His goal was for the program to rival and eventually overtake the entire educational infrastructure under the Ministry of Education. ${ }^{15}$

This ambitious reform required someone to head up the necessary tasks and manage the day-to- day Bureau affairs. Russell personally selected George F. Freeman for the job. He found Freeman through an advertisement that began with three qualification requirements that captured an unintended irony: "White, no racial prejudice, agricultural expert." ${ }^{16}$

Freeman had a solid background in science, became the darling of foreign capital interests in Haiti, and established a poor track record in terms of race relations. He had a doctorate in science from Harvard University where he developed an interest in large-scale agricultural production. Before arriving in Haiti, he had been Chief of the Division of Cotton Breeding at the Texas Agricultural Experiment Station. Almost as soon as he became Haiti's Director of the Technical Bureau in 1923, Freeman began using funds at his disposal to support the interests of American investors through the establishment of experiment stations. Research, instruction, and support offered by these stations came from an American staff selected by Freeman who were known for speaking only English. By default this arrangement favored large-scale foreign interests while marginalizing French-speaking natives and their small farms. The significance of Freeman's operation increased as American sugar and coffee companies consolidated and expanded their landholdings in Haiti. Over 170,000 acres of prime 
farm lands were acquired by these investors under the U.S. occupation. The power, resources, and tactics of these large-scale operations had the predictable consequence of wiping out small-scale Haitian farmers. Many who once owned their land soon found themselves working as labourers for foreign companies. Freeman's prejudices shaped his understanding of the situation. These black natives were not suited for self-rule, he believed, and if Haitians were to advance they would need to view themselves first as "human instruments" of commercial interests. Only then might "true leaders and teachers" follow to govern and educate the masses. He practised what he preached and turned the experiment stations into tools for industry, but the stations were just the beginning. ${ }^{17}$

Russell had Freeman use the Technical Bureau to carry out a total reform of Haitian education. To do this, Freeman received what amounted to a blank cheque. He also received important words of support from Russell who stated that if reforms were to succeed then traditional "primary and secondary instruction must necessarily await [funding]" because "the energies of the Haitian Government at present should be directed along lines of agricultural development and training and vocational instruction." Over the objections of the Haitian government, Freeman began by establishing the École Centrale d'Agriculture in 1924. Its purpose was to train agricultural technicians and to serve as a centerpiece for the proposed network of agricultural and technical institutions. Following the École Centrale, the Bureau invested heavily in the construction of farm schools and industrial schools that began appearing across the country. They would be, Freeman argued, better than the old, classical schools that draw "a child's mind to fanciful dreams of better things far away." The new schools taught about the here and now — farming, shoemaking, iron works, masonry, and bricklaying - with a curriculum divided in two parts. Approximately half of the instructional time centered on manual labour and the other half on basic reading, writing, morality, catechism, civics, and hygiene. To pay for on-going school construction and fund their operations, the budget for Freeman's division had to increase significantly. Russell happily complied. By 1929, Freeman was receiving 4.5 million gourdes for a total of 69 agricultural and vocational institutions. This was more than two times Russell's allocation to all other public schools combined, including 608 public elementary, secondary, and post-secondary schools. ${ }^{18}$

With this redistribution of Haitian funds, Russell had circumvented the democratic process that would have required working with the Haitian government on educational policy. He succeeded in building the schools he thought Haiti needed most. ${ }^{21}$

\section{Conflict}

But there was a problem. Haitians, by and large, rejected Farnham's vision of the country's future, Russell's educational policies, and Freeman's agricultural and vocational schools. No matter how many schools the Technical Bureau opened, they still needed students to fill the classrooms. And while denied the formal democratic process, students could vote with their feet. Very few (ten percent of the Haitian 
Table 1

U.S. Military Occupation Government Budget Allocations 1928-1929

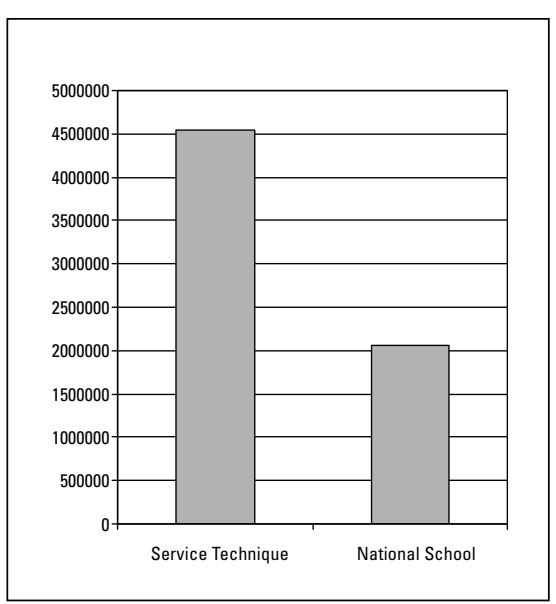

Table 2

\section{Haitian Student Population \\ Distribution 1928-1929}

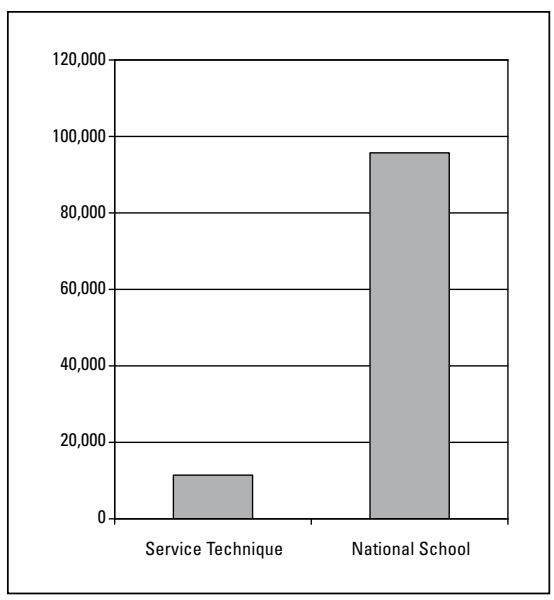

student population) ever enrolled in the Bureau's new programs. The National School System, on the other hand, with ninety percent of the nation's students, had to make do with a budget considerably less (approximately sixty percent less) than that of the Bureau. ${ }^{22}$

What Russell had dismissed too quickly was Haiti's well-established system of classical or traditional education that was a central part of Haitian culture; this tradition wasn't likely to change in a year or two or even a decade. The country's classical education had formed roots under the shade of French colonialism and had become part of the Haitian social order. Haiti established a national Ministry of Education in the 1840s, around the time Horace Mann was proposing public education for the state of Massachusetts. Before the American occupation, Haiti had also created the office of the École Communales that provided for a network of rural and urban schools and, eventually, the National School System. The most prized form of education was the classical, Latin-Grammar schooling offered at the lyceums. Haitians viewed them as pathways to higher learning and social mobility. The few lyceums that existed offered a strictly academic curriculum with moral and religious instruction, language and literature studies (French, Latin, Greek, Spanish), history, geography, philosophy, law, political economy, and applied mathematics. While a small percentage of the population ever received this kind of education, it held an important place in the Haitian conception of education, democracy, and social progress. ${ }^{23}$

This historical and cultural reality was Russell's greatest blind spot, even though he had been warned. Haiti's President Louis Borno understood what the people wanted and told Russell that the educational reforms were likely to fail. Borno pleaded with him to reconsider the disproportionate emphasis on technical education; he wanted Haitians to have greater access to classical education through the National 
School System. Russell ignored Borno's concerns and suggestions. "Any change in the American policy at this time," he told Borno, "would be a tremendous blow." 24

As funds continued to pour into the Technical Bureau, large budgetary discrepancies came into plain view. Salary differences between National School System teachers and those in the Service Technique caused an uproar. Teachers in the National Schools were native Haitians and received approximately \$4-\$6 dollars a month. The vast majority of Service Technique teachers were white, American educators and received ten times the salary with ranges between $\$ 40-\$ 90$ dollars a month; some received wildly disproportionate salaries of $\$ 4000-\$ 5000$ per year. The Haitian press, such as the Nouvelliste, was outraged and described the Service Technique as a symptom of the occupation's general disregard for the people: "There exist great fiascos which cost the Haitian people large sums of money. . . . As for The Service Technique de l'Agriculture, they kept spending money, and spent it badly." The British Minister to Haiti also couldn't help noticing that Freeman's instructors were "made up to a great extent of men and women who neither speak a word of French nor have any special qualifications as 'experts,' but who have been dumped on the unfortunate Haitian budget at unnecessarily high rates." 25

Outcries over discrimination in teacher pay contributed to a groundswell of dissatisfaction over the American occupation and Haiti's loss of autonomy. The occupation's management of Haiti's internal revenue fell under increasing scrutiny. It placed Russell and other occupation leaders under pressure to explain their actions. As Haitians saw it, the disproportionate funding of the Technical Bureau came at the expense of the National Schools that still operated out of rented buildings, had poorquality teaching materials, and offered teachers rock bottom salaries at about fifteen cents per day. Worse still, Haitians made the inflammatory discovery that Russell had used "surplus" funds in the nation's budget to make advanced principal repayment to a $\$ 40$ million New York-backed loan. This move gave the impression that extra loan payments to Wall Street mattered more than repairing the crumbling National School System. Tensions skyrocketed. ${ }^{26}$

\section{Crisis}

Widespread Haitian frustration ultimately exploded over what started out as a small student protest in October 1929. The protest spread across the country and caught the occupation by surprise. It ignited the same fuel of repressed political dissent that led to the mobbing of President Sam. This time Freeman, Russell, and Borno were the targets.

The crisis began at Freeman's flagship École Central de l'Agriculture. Poor enrollments there proved to be an embarrassment to the entire technical education plan. To increase enrollments, Freeman received funds for a scholarship pool. The idea was to attract students by giving them a generous financial aid package that would enable them to attend. Midway through the Fall semester of 1929, Freeman decided to make an across the board cut of twenty percent to the scholarships students were receiving. He moved the "savings" to an experiment station and demonstration 
farm in the city of Damien. Students were expected to absorb the difference. When they learned of this decision, students formed a committee and met with Freeman in October 1929. It didn't go well. Freeman remained unmoved by their concerns and told them that if they were unhappy they could simply leave the school. They immediately responded by striking. Classrooms emptied and students marched approximately five miles to Port-au-Prince. Their objective was to appeal to the Haitian Minister of Public Instruction, Charles Bouchereau, whom they hoped might be able to represent their concerns to the American occupation. To their dismay, Bouchereau came across as siding with Freeman, telling them that they had to return to classes the next day. If they failed to do so, they'd be automatically withdrawn from school. He threatened them with a loss of their seats and aid at the institution. But this move only aggravated the situation. Students became more resolved to fight Freeman and what he represented-American control of Haiti. They declared their intention to continue the strike. ${ }^{27}$

Word spread quickly across the country that students had taken a stand against the occupation. During the month of November, Haitians from virtually all walks of life began to show their support and take a stand themselves. The Haitian League of the Rights of Man demanded an investigation into the Freeman controversy. Newspapers talked of his "drastic action against young men and girls." Students attending Haiti's professional schools of law, medicine, applied sciences, and teacher education signed formal declarations of support for the École Centrale rebellion. Students at a reform school joined the uprising with a hunger strike. Some Haitians took to the streets and even stoned Freeman's home. Others, including students and staff at the École Centrale and at the Service Technique school in Damien, began to demand Freeman's resignation. Toward the end of November, coordinated demonstrations were organized in Jacmel, Cap-Hatien, and St. Marc. Students in those towns left classes and poured into the streets to protest against the occupation. The strike turned into a movement that reached the very heart of the occupation. Haitian employees in the customs houses, banks, and commerce divisions under occupation control left their desks and protested against the military government's treatment of Haitian students. ${ }^{28}$

Russell, Freeman, and Borno attempted to deal with the crisis by increasing student financial aid in December 1929, but it was too late. Russell began blaming the strike for what appeared to be the beginning of the end of the occupation. He feared that protests were "rapidly spreading throughout Haiti" and wanted to suspend freedom of the press because "invitations to disorder were daily printed." Meanwhile, student and parent groups asked to meet with Freeman. The director refused their request, creating an uprising among faculty and staff at the École Centrale. They threatened to resign if Freeman continued to rebuff requests for a meeting. When he finally agreed to one, observers described it as "apparently acute." Nothing came of it, prompting Borno to step in and replace Minister of Public Instruction Bouchereau with Hannibal Price. He hoped a change of guard might appease critics. Price immediately tried to stem the crisis by guaranteeing École Centrale students jobs upon graduation, returning scholarships to their original amount, and working the press to promote the latest round of concessions. ${ }^{29}$ 
None of these moves slowed the Haitian protest movement. It had taken on a life of its own and transformed into demands for the end of the American occupation. Russell panicked. He ordered marines in Haiti back to their barracks, requested more troops through contacts at the State Department, and prepared for battle. In a show of force, he ordered select military units to parade their equipment and machine guns across the country. He hoped the population would back down. They didn't. About one thousand Haitians charged a group of marines stationed on the outskirts of Cayes, resulting in the death of five Haitians and the wounding of twenty others. ${ }^{30}$

\section{Commissions}

The occupation's collapse appeared imminent. Borno, aware that his own presidency depended on the occupation, tried to arrest twenty political opposition leaders, but Russell refused the order. News of the crisis reached Washington and President Hoover responded by requesting a special Commission to investigate the situation. He got two of them: the Forbes Commission and the Moton Commission. The first was made of an all-white group and the other, with the exception of one member, was all-black. ${ }^{31}$

Cameron Forbes led the first commission. He came from a prominent business family that had amassed fortunes in the railroad industry and the Bell Telephone Company. He was chosen for the task partly because he'd previously served as Governor of the Philippines during the early stages of that occupation. While in the Philippines, Forbes believed that attracting American investment was more important than building up schools. It was a belief much like the ones held by Farnham, Russell, and many others of their generation. "I have suggested that we build roads first and schools afterwards," Forbes stated, indicating that once foreign investment flourished so too would the availability of funds for the development of education. As for schools that best suited the Filipino, he claimed that "we want men taught to work with their hands. . . we want to see agricultural schools and arts and trades schools in greater abundance." These were the experiences and propensities Forbes brought with him to the Hoover Commission. His charge was to examine the general social, political, religious, and economic conditions of occupied Haiti. His team was to provide an honest assessment of the conditions on the ground and whether it was time for the U.S. military to pull out. ${ }^{32}$

The Forbes Commission travelled on the Navy's U.S.S. Rochester and spent ten days in Haiti to gather information for their report. Forbes placed some of the blame squarely on "the failure of the Occupation to understand the social problems of Haiti, its brusque attempt to plant democracy there by drill and harrow, its determination to set up a middle class - however wise and necessary it may seem to Americans, all these explain why, in part, the high hopes of our good works in this land have not been realized." Forbes also commented on the "racial antipathies" of the occupation that "lie behind many of the difficulties." American military forces understandably, implied Forbes, didn't know how to respond to "a highly cultured, highly sophisticated" society made of the "Negro race" that had enjoyed freedom and developed 
"race-conscious leadership." The report recommended that Borno should step down and be replaced with an interim president until a general election could be held. It favored a gradual military withdrawal and selective replacement of U.S. occupation officials with others more sympathetic to the Haitian people. At the same time, the Forbes Commission defended the rights of foreign landowners, such as U.S. corporations, who had acquired large tracts of land under the occupation. They believed that these acquisitions should remain legal and intact, although they supported the desire on Haiti's part to rewrite the constitution or reform land policy for all future land acquisitions. ${ }^{33}$

The Moton Commission was led by Robert Moton, President of the Tuskegee Institute. A graduate and later "commandant" of the Hampton Institute (18911915), Moton worked at the Tuskegee Institute as Booker T. Washington's successor. He was well-known for having turned Tuskegee into a college-level institution. Moton had spent a lifetime in technical and industrial education for the AfricanAmerican community. ${ }^{34}$

The selection of a black committee under Moton raised eyebrows among the African-American press. Some considered it a "Jim Crow" move that segregated the white, politically-oriented Forbes Commission from the black, technical educationoriented Moton Commission. Others questioned whether Moton was in a position to do much good in assessing the true educational needs of Haiti. Still others saw this as a transparent attempt by Hoover to win black votes. Whatever the case, many viewed the Hoover administration as "anti-Negro to the bone" for separating the two commissions. ${ }^{35}$

When called to serve on Hoover's Commission on education, Moton wanted to silence critics by demonstrating that both commissions were of separate but equal importance. So he made a simple request. He asked for the two committees to travel together. Acting Secretary of State Joseph Cotton worried about "the embarrassment and complications which would ensue if we ask the Navy to provide accommodations for Dr. Moton on the Rochester." The State Department, however, gave the excuse that the Moton Commission should wait to go to Haiti after political tensions had subsided. Since tensions were in large part over educational policy, Moton agreed to wait. Once Moton's group was given approval to go, he made another simple request. He asked for the same mode of transportation given to the Forbes Commission. Moton wanted the Rochester. He claimed that the America black press would dub the Hoover administration as racist if it denied the request. This fell on deaf ears. The State Department replied that the Navy might have a minesweeper that could be made available to them. Feeling "Jim-Crowed," as one member put it, they decided to travel by commercial steamer. Their visit to Haiti lasted twenty-four days. ${ }^{36}$

Moton's Commission had a narrow charge - to study the state of Haitian education and offer recommendations. Freeman was still Director of the Technical Bureau at the time. When he discovered that a black commission would review educational policies in Haiti, Freeman immediately submitted his resignation. He told Russell he was "very anxious to leave at once." The timing and urgency of his hasty departure raised suspicions among the Moton Commission, especially after they discovered 
that after fifteen years under U.S. occupation only about twenty-five percent of Haiti's school-aged children were attending school. They blamed the poor enrollment figures on the lack of school facilities. The entire country had approximately 1100 schools that served one-fourth of an estimated 400,000 school-aged children. Student-teacher ratios were 70:1 at the elementary level. The commission identified low teacher salaries, lack of equipment, and inadequate teacher training as important factors contributing to the dismal state of Haitian education. But the primary reason for these "shortcomings" was the costly and misguided creation of a "distinct and separate system of schools" run by the Agriculture Department. Moton's team recommended the creation of a unified system under the direction of Public Instruction, increases in teacher salaries based on preparation, Haitian-based teacher training, school building programs, and a freeze on the expansion of Service Technique schools. ${ }^{37}$

While calling attention to the Service Technique, dubbing it a wasteful educational reform effort, Moton believed that problems ran deeper in occupied Haiti. It wasn't just an issue of mismanagement and ill-conceived educational policy. His real concern was in the occupation's general approach to Haiti, influenced as it was by American business interests. "Had there been less of a disposition," he argued

to deal with the island as a conquered territory and more to help a sister state in distress, less of a desire to demonstrate efficiency and more to help others to the efficient direction of their own affairs, less of enforced control and more of helpful cooperation, the United States might today have greater reason to be proud of her intervention in the affairs of a struggling neighbor. ${ }^{38}$

Moton's concerns displayed a sensitivity to the gap between rhetoric and reality. He understood that the U.S. intervention began with a hopeful, humanitarian spirit, but was soon overtaken by the spirit of enterprise and efficiency. Here Moton suggested that capital eclipsed compassion.

Unlike the Forbes report, which was met with a positive reception, the Moton report never had a chance. It was shunned by W.W. Cumberland, a former financial advisor to Haiti, as "maliciously erroneous." A former Service Technique official said the report sounded like "Nigger to Nigger" to him. The State Department demanded revisions to Moton's final document. When Moton refused the order, State issued a public, preemptive warning about the commission. They described Moton's assessment as riddled with "misconceptions" and "incorrect information." What's more, there was a virtual blackout of Moton's report. It wasn't announced to the public when it was released. ${ }^{39}$

Many in Congress followed the commissions carefully, weighing the benefits and drawbacks of leaving a military government in place in Haiti, but others, like George Huddleston from Alabama, believed all this business about commissions and reports was a waste of time. Huddleston didn't think a collection of "high hats and longtailed coats" poking around the countryside would reveal anything new. To his mind, the truth of the matter was that the U.S. invaded and occupied not for uplift or "political tutelage" but because of greed from the American business community. Why 
else, he wondered, do Americans control the "only really valuable harbor in Haiti," the most fertile lands in the country, the market on some of the "cheapest labor in the world" at twenty cents per day, and the nation's debts and bonds purchased at "great discounts." The intervention began by executive order and should end by the same means, he argued. Commissions would just delay the process of ending the intervention in Haiti. ${ }^{40}$

Huddleston had a clear understanding of the economic influences that intersected with the U.S. occupation, but he spoke too soon when it came to his assessment of the value of commissions. Whatever their reception, the commissions had the net effect of rapidly accelerating the transfer of power to Haitians and the complete withdrawal of American troops in 1934. The original treaty allowed for the occupation to last until 1936. The commissions helped trim that by two years. Until the riots and protests, there was no indication that the U.S. was preparing for withdrawal. The commissions exposed what many in Congress had originally feared. Some had become resigned to the fact that Borno was merely "a puppet" of the occupation. Others viewed the occupation as little more than an "attempt to justify the imposition of our will and authority upon another people." President Hoover and Congressional leaders were indicating that they'd had enough, and the commissions gave them cover for their positions. Russell attempted to defend the occupation from criticism. After fifteen years under U.S. rule, Haiti's infrastructure improvements included 153 rural clinics, 11 modern hospitals, the registration of 2800 automobiles, a tripling of the nation's bridges, and 800 new miles of road. Russell had also built up the Haitian Gendarmerie, the country's military police, to just under 3000 strong. The country, he thought, was unmistakably better off. ${ }^{41}$

But of all the criticism that came from Capitol Hill, there was one critical point Russell had failed to address. It had to do with the problem of education and democracy. Hamilton Fish III, Representative from New York, stated frankly that "we have not lived up to our agreement to try to educate the Haitian people to some form of self-government." ${ }^{42}$

\section{Conclusion}

The U.S. occupation of Haiti was presented to the American public as a humanitarian mission. President Sam's fall made this easy to understand. Before the troops arrived in Port-au-Prince, however, pressures from American banking and corporate interests transformed a mission launched for public good into one for private gain. Haiti is not alone. Scholars have long unearthed similar circumstances in the American occupations of Cuba, the Philippines, Puerto Rico, the Dominican Republic, among other interventions.

What the occupation of Haiti suggests is that a very real potential for conflict between capital and democracy existed. The commissions and debates in Congress revealed that the occupation had succeeded in satisfying American economic interests, but had failed to promote democracy through education. Farnham, Russell, and Freeman explicitly saw the occupation as a vehicle for the promotion of economic 
interests. They were, in a sense, "soldiers of fortune."

None of this was news to Major General Smedley Butler, who'd helped train the Haitian Gendarmerie during the American occupation. He understood the problem from the inside and, a year after the occupation ended, made public an account of how commercials forces shaped foreign policy-making decisions: "I helped make Haiti and Cuba a decent place for the National City Bank boys to collect revenues in. I helped in the raping of half a dozen Central American republics for the benefit of Wall Street." "The record of racketeering," he continued, "is long."

I helped purify Nicaragua for the international banking house of Brown Brothers in 1909-1912. I brought light to the Dominican Republic for American sugar interests in 1916. I helped make Honduras 'right' for American fruit companies in 1903. . . . Looking back on it, I feel I might have given Al Capone a few hints. The best he could do was operate his racket in three city districts. We Marines operated on three continents. ${ }^{43}$

While Butler described military-corporate occupations abroad, Congressman Huddleston sized up more directly what the Haitian intervention might mean for Americans back home. He understood this as well as anyone from the outside, and believed that there were domestic implications for what the U.S. does on foreign soil. "We can not exist as an imperialism abroad and a democracy at home," he asserted on the floor of Congress, and "we can not exist as a tyrant in foreign countries and a free people in the United States. We can not hold securely upon our liberties here and take them away from people that live in other parts of the world - poor or ignorant or whatever they may be, the consequences will come back to us - the recoil will fall on us." ${ }^{44}$

The warnings of the Butlers and Huddlestons of the era have been largely drowned out by clamor for continued U.S. interventionism from the War of 1898 to the War on Terror. What the occupation of Haiti puts in sharp relief is the significant relationship between capital and education in American attempts to promote democracy abroad.

\section{Notes}

1 The story of America's first occupation of Haiti has been told many times. Scholars have closely examined the social, political, economic, and military dimensions of this intervention. Hans Schmidt's The United States Occupation of Haiti, 1915-1934 (rev. ed., New Brunswick: Rutgers University Press, 1995) and Mary A. Renda’s Taking Haiti: Military Occupation and the Culture of U.S. Imperialism (Chapel Hill: University of North Carolina Press, 2001) remain two of the most comprehensive works on the topic. Despite these and other excellent histories, there have been very few sustained analyses of education during the occupation. Much of the work in this area is atomized and fragmented. Of late, Leon D. Pamphile's Clash of Cultures: America's Educational Strategies in Occupied Haiti, 1915-1934 (Lanham: University Press of America, 2008) is the only book-length work that explicitly aims at filling the historiographical gap. 
2 For examples of the different approaches to America as empire, see the following: Stephen Howe, Empire: A Very Short Introduction (Oxford: Oxford University Press, 2002); Niall Ferguson, Colossus: The Price of America's Empire (New York: Penguin Press, 2004); Charles S. Maier, Among Empires: American Ascendancy and its Predecessors (Cambridge, Mass.: Harvard University Press, 2006); Walter T. K. Nugent, Habits of Empire: A History of American Expansion (New York: Alfred A. Knopf, 2008); Julian Go, American Empire and the Politics of Meaning: Elite Political Cultures in the Philippines and Puerto Rico during U.S. Colonialism (Durham: Duke University Press, 2008). On approaches to education and empire, see Glenn Anthony May, Social Engineering in the Philippines: The Aims, Execution, and Impact of American Colonial Policy, 1900-1913 (Westport: Greenwood Press, 1980); Judith Raftery, “Textbook Wars: GovernorGeneral James Francis Smith and the Protestant-Catholic Conflict in Public Education in the Philippines, 1904-1907," History of Education Quarterly 38 (Summer 1998), 143-164; Jose-Manuel Navarro, Creating Tropical Yankees: Social Science Textbooks and U.S. Ideological Control in Puerto Rico (New York: Routledge, 2002); Anne Paulette, "To Change the World: The Use of American Indian Education in the Philippines," History of Education Quarterly 47 (May 2007), 173-202.

3 The central literature on Haiti is as follows: Schmidt, Occupation of Haiti; Renda, Taking Haiti; Pamphile, Clash of Cultures; Magdaline W. Shannon, Jean Price-Mars, the Haitian Elite and the American Occupation, 1915-1935 (New York: St. Martin's Press, 1996); Brenda Gayle Plummer, Haiti and the Great Powers, 1902-1915 (Baton Rouge: Louisiana State University Press, 1988); Robert M. Spector, W. Cameron Forbes and the Hoover Commissions to Haiti (1930) (Lanham: University Press of America, 1985); David Healy, Gunboat Diplomacy in the Wilson Era: The U.S. Navy in Haiti, 1915-1916 (Madison: University of Wisconsin Press, 1976); Emily Greene Balch, ed., Occupied Haiti (rev. ed., New York: Negro Universities Press, 1969); Arthur C. Millspaugh, Haiti Under American Control, 1915-1930 (rev. ed., Westport: Negro University Press, 1970); Dana G. Munro, Intervention and Dollar Diplomacy in the Caribbean, 1900-1921 (Princeton: Princeton University Press, 1964); John A. Vernon, "Racial Gamesmanship and the U.S. Occupation of Haiti: An Illustrative Episode," Alabama Historical Quarterly 40 (1978), 144-161; Richard Millett and G. Dale Gaddy, "Administering the Protectorates: The U.S. Occupation of Haiti and the Dominican Republic," Revista Interamericana 6 (1976), 383-402.

4 Bryan quoted in Schmidt, Occupation of Haiti, 48; for an account of Haiti's history during the lead up to the invasion, see Plummer, Haiti and the Great Powers.

5 On Bryan's relationship to the banking industry, see Matthew Simon, "The Hot Money Movement and the Private Exchange Pool Proposal of 1896" Journal of Economic History 20 (1960), 31-50; Paola E. Coletta, "William Jennings Bryan and Currency and Banking Reform," Nebraska History 45 (1964), 31-57; Farnham's relationship with Bryan recounted in Munro, Intervention, $332 \mathrm{ff}$.

6 Navy Department, "Plan for Landing and Occupying the City of Port-au-Prince [1914]," cited in Schmidt, Occupation of Haiti, 64; Farnham's executive and political roles described in Plummer, Haiti and the Great Powers, 169-171; and Schmidt's "Haiti before the Intervention" and "Decision to Intervene," in Occupation of Haiti, 10-63. The decision to remove the Haitian government's gold was also likely motivated by Haiti's refusal to complete payments on the National Railway of Haiti (headed by Farnham). The 108 miles of railway completed lay in three disconnected sections over non-mountainous area. Haiti refused to pay the maximum agreed upon amount of $\$ 33,000$ per mile, citing lack of completion. For further discussion on the National Railway project, see Healy, Gunboat Diplomacy, 29-34, 54-58.

7 Secretary of State Robert Lansing quoted in Schmidt, Occupation of Haiti, 67; on earlier U.S. interventions in Haiti, see Schmidt, Occupation of Haiti, 31. Banking and railroad 
interests had approximately $\$ 4$ million invested in Haiti with concessions to cultivate 3240 square miles of land (fifteen miles each direction from the railroad of 108 miles). See Plummer, Haiti and the Great Powers, 156.

8 Munro, Intervention, 368-371; Schmidt, Occupation of Haiti, 118. Franklin Delano Roosevelt stated in a campaign speech that "I wrote Haiti's constitution myself, and if I do say it, I think it is a pretty good constitution." FDR quoted in James McCrocklin, Garde D' Haiti, 1915-1934: Twenty Years of Organization and Training by the United States Marine Corps (Annapolis: United States Naval Institute, 1956), 74.

9 Harding quoted in Schmidt, Occupation of Haiti, 118. See also, Spector, Hoover Commissions, 39.

10 Pamphile, Clash of Cultures, 24-26; Munro, Intervention, 365-384.

11 Farnham quoted in Pamphile, Clash of Cultures, 96. At the start of the occupation, education ranked near the bottom on the list of priorities. On-going rebellion, sanitation issues, infrastructure, and unemployment consumed much of the early work of U.S. officials who took over leadership roles in Haiti. Only as stability increased and resistance waned did the U.S. military begin to take seriously the role of education in supporting American interests.

12 Russell quoted in Pamphile, Clash of Cultures, 42; Russell quoted in Millspaugh, American Control, 110. Russell took charge of the American military occupation in Haiti from 1918-1930. He had the added distinction of being Haiti's "High Commissioner" from 1922-1929. During the first few years, he supported "corvee" or the policy of forced labor for Haitians for infrastructure projects.

13 Spector, Hoover Commissions, 19; Pamphile, Clash of Cultures, 54, 70, 72, 106. Russell viewed uneducated Haitians as "more or less of an animal, who will do whatever he is told." Quoted in Schmidt, Occupation of Haiti, 125.

14 Pamphile, Clash of Cultures, 92-93.

15 Schmidt, Occupation of Haiti, 182-185; Pamphile, Clash of Cultures, 75-77.

16 Pamphile, Clash of Cultures, 76.

17 Schmidt, Occupation of Haiti, 177-178, 180-182, 185; Pamphile, Clash of Cultures, 76-78; United States, Congressional Record 72 (December 18, 1929), 916; Balch, ed., Occupied Haiti, 32, 82-84.

18 According to the Hoover Commissions (1930), the National School System consisted of 217 urban primary, 384 rural primary, six secondary, and one superior (University of Port-au-Prince) schools, or a total of 608 institutions. See, Spector, Hoover Commissions, 161, 164; Balcher, Occupied Haiti, 85; Russell and Freeman cited in Pamphile, Clash of Cultures, 79, 81, 106.

19 The Service Technique received 4,550,257.20 Gourdes; the National Schools, 2,053,664.29 Gourdes. See Review of Finances - Republic of Haiti, 1924-1930 and Annual Report of the Service Technique, 1929-1930, cited in Pamphile, Clash of Cultures, 106.

20 The Service Technique had 11,430 students; the National Schools, 95,696. Numbers are estimates provided by the U.S. Military occupation government. See, "Bulletin Officiel du Departement de l'Instruction Publique" (Oct-Nov 1928) and Annual Report of the Service Technique, 1929-1930 cited in Pamphile, Clash of Cultures, 106.

21 Russell never believed in power-sharing with the Haitians. "The absurdity of dual control, or of two nations administering the affairs of a country" he asserted, "is too obvious to need comment." Quoted in Schmidt, Occupation of Haiti, 124.

22 Spector, Hoover Commissions, 161-164; Pamphile, Clash of Cultures, 106.

23 For a discussion on Haiti's pre-occupation history of education, see Pamphile, Clash of Cultures, 1-21.

24 Pamphile, Clash of Cultures, 91. 
25 Pamphile, Clash of Cultures, 107-111; United States, Congressional Record 72 (December 18, 1929), 914.

26 Spector, Hoover Commissions, 164; Pamphile, Clash of Cultures, 118. What's more, reports indicated that few Haitians ever attended secondary schools. Statistics indicated that out of every 1000 Haitians, a mere 2.8 had schooling beyond the elementary level. In the U.S., out of every 1000 African-Americans, there were almost 10 (9.8) who had reached the secondary level. Spector, Hoover Commissions, 166.

27 This and the following discussion about student protests are based on Schmidt, Occupation of Haiti, 196-206; and Pamphile, "Student Strike Triggers National Crisis over American Educational Policy," in Clash of Cultures, 124-153.

28 Pamphile, Clash of Cultures, 124-134.

29 Schmidt states that Russell also imposed martial law and a curfew. See, Occupation of Haiti, 198; Pamphile, Clash of Cultures, 124-134.

30 Pamphile, Clash of Cultures, 124-134.

31 The most comprehensive treatment of the commissions can be found in Spector, Hoover Commissions.

32 On Forbes's background and term in the Philippines, see Glenn May, Social Engineering in the Philippines: The Aims, Execution, and Impact of American Colonial Policy, 1900 1913 (Westport: Greenwood Press, 1980), 21, 113. Forbes was also known for working for British, Belgian, and French stockholders of the Brazilian Railway Company from 1914-1920 as sole receiver of the operation valued at three hundred million dollars with thirty-eight corporations in five South American countries. In his later years, Forbes vacationed in Honduras where he was a director of the United Fruit Company.

33 Spector, Hoover Commissions, 144-145; Vernon, "Racial Gamesmanship," 149; Pamphile, Clash of Cultures, 137.

34 For more on Moton, see William H. Hughes, Robert Russa Moton of Hampton and Tuskegee (Chapel Hill: University of North Carolina Press, 1956).

35 Vernon, "Racial Gamesmanship," 150.

36 Vernon, "Racial Gamesmanship," 152, 157; Pamphile, Clash of Cultures, 140.

37 Pamphile, Clash of Cultures, 140, 142; Spector, Hoover Commissions, 161-164; Moton was hardly the only one with strong words about the occupation's mishandling of education in Haiti. See also Balch, Occupied Haiti, 93-108.

38 Report of the United States Commission on Education in Haiti, 73.

39 Pamphile, Clash of Cultures, 147, 149.

40 United States, Congressional Record 72 (December 8, 1929), 912.

41 United States, Congressional Record 72 (December 8, 1929), 910, 911; Schmidt, Occupation of Haiti, 214.

42 United States, Congressional Record 72 (December 8, 1929), 911

43 Butler quoted in Ferguson, Colossus, 58-59; see also, Hans Schmidt, Maverick Marine: General Smedley D. Butler and the Contradictions of American Military History (Lexington: University Press of Kentucky, 1998), 74-95, 231.

44 United States, Congressional Record 72 (December 8, 1929), 923. 